\title{
Relevance and the Translation of Poetry
}

\section{Marta Dahlgren Thorsell University of Vigo}

\begin{abstract}
The analysis of poetry brings up questions that are normally not asked when analysing prose, at least not in the case of descriptive prose. This study was originated in the analysis of translated poetry and touches on controversial issues where many dogmas still stand unchallenged. Poetry and poetic prose are areas where the discourse is supposed to emphasize "connotation" rather than "denotation." Connotations are supposed to be subjective and therefore not amenable to serious research activity. This paper discusses the categories of overt and covert translation and offers a tentative approximation to an application of the tools of pragmatics to the analysis of selected poems and their translations. It is contended that the concept of relevance can be applied to poetry to explain -and perhaps limit- interpretations open to readers.
\end{abstract}

\section{Introduction}

An indication as to the limited scope of this study has been given in the abstract. To discuss poetry is treading on dangerous ground, and the application of linguistics to poetic discourse in an attempt to "explain how it works" has always produced attacks both from authors and scholars. This is not a treaty on poetry. It is not a poetics of translation. Simply, the idea of applying pragmatics to poetry was triggered by comparisons of originals and translations of poems. Pragmatics has been applied to dialogues in fiction with interesting results, lately also incorporating analyses of dialogues and surrounding narrative discourse (see for example Varela, 1993). Another text that furnished the idea that there are translations that 
are not born from the translator's poetic intuition (whatever that is) but from serious analysis and probing of different lines of inference is Guy Leclercq's analysis of Verlaine's Pantomime. Leclercq goes into the minutest detail of his source text before venturing a translation, because his aim is twofold: "faire de la poésie, respecter le texte."(Leclercq 199?:70).

\section{Poetic language?}

Wellek and Warren, as far back as in 1942, said that "Meanings, context, and 'tone' are needed to turn linguistic sounds into artistic facts." (Wellek and Warren, 1977:160). This claim is based on the idea that poetry is a series of sounds out of which arises a meaning. Sounds are arranged according to stress and pitch, recurrence, position of rhythmical units and other elements that together furnish what has misleadingly been called the 'musicality' of a poem. Wellek and Warren go on to state that effects that we take to be sound-induced are very often dependent on meaning, and quote John Crowe Ransom's well-known example "the murmuring of innumberable bees" as compared with "the murdering of innumerable beeves" (Wellek and Warren 1977:162). Another quite amusing example of what a translator believes can be used to create 'musicality' comes from a recent publication by Elisabeth Gamble Miller in Translation Review:

In translating the poem /by Nela Rio/, the translator's particular concern was finding poetic measures that would set the poignant tone. The resulting English text is not as lengthy as the Spanish; it has fewer syllables, but the translator used sibilants in stressed words... (Miller, 1996:12).

The Spanish line "El tiempo tiene el sonido de campanas" therefore becomes "Time has the sound of bells", where, Miller says "the onomatopoeic word "sound," accompanying the image of bells may compensate for the longer length of the Spanish lines." (Miller 1996:13). Here we have a clear confusion between semantic, conventional meaning and onomatopoeia: both sonido and sound contain sibilants but that does not make them onomatopoeic! What we have here is quite simply a word-for-word translation!

If the semantic component in poetry is in fact the most important one, we may ask ourselves to what degree this influences interpreting and translating of poetry. A look at selected poetry in translation does give the -perhaps surprising-impression that renderings based on semantic meaning are far more common than imitation of rhythm and sound. This gives as a result translations with not only literal but word-for-word correspondence to the original. To substantiate such a claim, a statistical study would have to be carried out. In the meantime, reference can be made to studies on the translation of poetry published both by poets and translation scholars, and very especially to studies by scholars who are also poets. More will be said about this at a later stage. 


\section{Connotation and inference}

Literary analysis of poetry applies rhetorics terminology that is in fact also applied to descriptive prose, in both instances to account for formal set-ups. There are, evidently, effects in both genres that can not be explained by formal analysis, and this is the reason why pragmatics can be considered helpful.

In pragmatics the term connotation is replaced by reference to the type of discourse that habitually triggers inference, and discourse where explicatures are replaced by implicatures, and the coded part of an utterance cannot be simply decoded and understood as a straightforward proposition. Sperber and Wilson refer to this question in the following terms:

There is a very good reason for anyone concerned with the role of inference in communication to assume that what is communicated is propositional: it is relatively easy to say what propositions are, and how inference might operate over propositions. No one has any clear idea how inference might operate over non-propositional objects: say, over images, impressions or emotions. Propositional contents and attitudes thus seem to provide the only relatively solid ground on which to base a partly or wholly inferential approach to communication. Too bad if much of what is communicated does not fit the propositional mould.

At first sight, it might look as if semioticians had a more comprehensive view. They have an a priori account of how any kind of representation, propositional or not, might be conveyed: namely, by means of a code. However, studies by semioticians of what they call 'connotation', i.e. the vaguer aspect of what is communicated, are highly programmatic and do not offer the beginnings of a psychologically adequate account of the type of mental representation involved. The semiotic approach is more comprehensive only by being more superficial (Sperber and Wilson 1986:57).

Vagueness is being dealt with in vague terms, say Sperber and Wilson, whose intention it is to determine where the coding-and-decoding system ceases to be useful when analysing how the addressee interprets an utterance. They speak about the communicator's intention: to modify the cognitive environment of the audience. To achieve such a modification, the context is of extreme importance. An example of a very simple utterance that would be sheer nonsense out of context could be

\section{At 5.25.}

which acquires meaning only in the context of a question-and-answer environment such as a passenger asking for the arrival time of a train. This would be precise information, ostensive, and strongly communicated in the right environment. What happens if the communicator's intention is to increase the vagueness of her communication, and to include a wide range of assumptions, all of which have to be inferred by the hearer? In this case 
decoding is not sufficient to interpret meaning. Let us now jump from the exchange of information in

1 (Passenger) When does this train arrive at Oxford?

2 (Ticket collector) At 5.25.

where communicative success depends on the intention to give clear and straightforward information, to the extreme opposite: deliberate ambiguity. To this end, we use a stanza taken from a poem by Paul Élouard, translated from the original French into English by another poet, Samuel Beckett.

Le sang coulant sur les dalles

Me fait des sandales

Sur une chaise au milieu de la rue

J'observe les petites filles créoles

Qui sortent de l'école en fumant la pipe.

(Confections, 15th stanza, as quoted in Remy, 199?:XII)

The last two lines can be read in two ways: "J'observe les petites filles créoles en fumant la pipe" or "J'observe les petites filles créoles (qui) sortent de l'école en fumant la pipe."

In a real-world situation, just like a situation where a train passenger inquires about the arrival time, old men who watch little girls as they (the girls) come out of school are the ones who smoke pipes. The poet presents the image of an old man smoking a pipe. This is the interpretation we would claim to be adequate after devoting the minimum amount of effort to understanding these two lines. But after reading the warning the poet issues by means of an indirect speech act:

Il ne faut pas voir la réalité telle que je suis.

the reader has to go back and call up another image. This image requires more effort to retrieve. Knowledge about surrealist writing and visual art is necessary for poet and reader to have a mutual cognitive environment. For a surrealist, what is there to keep a girl from smoking a pipe? Now to the translation. It goes as follows:

I observe the little Creole girls

Coming out of the school smoking pipes.

The translator has chosen to stress - perhaps overstress - the surrealist environment. Stanza 16 has been translated "Do not see reality as I am." The indirect speech act has become a direct warning: nothing in this poem can be taken for what it seems, the poet wishes us to create a surrealistic picture in our mind. Ergo, the translator's choice is 
warranted. But the ambiguity, in this case caused by a feature of syntax, which is just as easy to express in the English version as in the French one, has been totally lost.

\section{Overt and covert translation}

According to House 1981, covert translation takes place when the translation is not marked as a translated text of a source text but may have been created in its own right. In covert translations we very often have some kind of functional equivalence - the poem is recognized as a poem, but meaning transfer is not necessarily included in the bargain - and the original is often not considered, and if it is, it does not matter if the comparison shows divergence, because the translation has achieved the status of an original in the target culture. Texts that are crucially dependent on the source language original would be interpreted and read differently depending on whether they were presented as works in their own right or as representations of source language originals. In translation for the scene, "versions" that differ from the source text are very often produced, and objections raised as to fidelity are countered with the claim that the text has to work with the target language audience. When translating poetry, similar considerations are often voiced. The problem for the translator is then how to decide what changes can be warranted by regard for the target language audience and what has to be preserved in order not to produce a completely new piece of discourse.

E.A. Gutt, in his book Translation and Relevance says that in the cases indicated

the receptor language texts are intended to achieve relevance in their own right, not in virtue of their interpretive resemblance with some source language original (Gutt 1991:57).

The idea that the main aim of poetry is to cause the same or at least a similar effect as the original is not a new notion. This kind of translation was advocated by Nida and Taber already in 1969.

... the message is conveyed by means of dynamic translation, conveying the total meaning or content of a discourse; the concepts and feelings which the author intends the reader to understand and perceive (Nida and Taber, 1969:205).

This is an author-centered approach. Author-based analysis has long been replaced by theories of reception and it can be argued that it is the reader's world-view and experience that counts for the retrieving of meaning in literature and very especially in a poem. The poet makes use not only of explicit information, but also information that is not given but derived from some specific linguistic expression - that is, inferred from it. Some words are inference-triggers in most languages, but the line of inference can vary from one to the other. A standard and perhaps slightly worn-for-wear example here is the word "fox", and 
even much more so the corresponding female "vixen" where the images differ greatly, as can be seen when comparing "vixen" in English and "zorra" in Spanish.

\section{Relevance-based interpreting of poetry}

What happens when the epitome of inference-triggering discourse, poetry, is translated? When transferring poetry from one language to another the question arises how to transform not only explicit but also implicit information. Implicit information might have been shared by the original author and her audience but not by the target language audience. Gutt argues that the difference between implicit information and information that is not expressed (simply absent) can depend on the speakers intention to convey it, but as the audience has no access to the communicator's intention, there is no way to tell one from the other. Misconceptions are due to appear in such cases. Examples here can be provided by the interpretation of metaphors. The idea that there is always one 'point of similarity' between the two parts present in metaphors is mistaken: the very point of figurative uses of language is that they convey a wider range of ideas, not present in either of the parts, and the problem is which to choose.

Relevance theory attaches great importance to processing cost. In poetry and poetic prose the extended search for relevance adds to the pleasure of interpreting. When we have an original that presents problems of interpretation, there are (at least) two ways of handling this: making the translation clearer and more understandable, more explicit, as it were, or maintaining the difficulty, which in most cases means making it more difficult to interpret. To return to Paul Élouard in Samuel Beckett's translation, in the case of the pipe-smoking little girls, the elimination of ambiguity changes the effect radically. The reader is not allowed even to spot the ambiguity. In the second case - when difficulty is maintained -there can be instances where the processing cost is simply too high: the fact that the derivation of such contextual implications would require great processing effort on part of the reader will have to make the poetry translator think twice. (see Sperber and Wilson 1986 and Carston 1991)

To say that a translation should communicate the same interpretation as the one intended in the original means that it should convey to the receptors all and only the explicit information and all and only the implied information that the original was intended to convey. The implicatures in the original are to be conserved, and a reshuffling of information - something considered a legitimate part of 'communicative approaches' to translation - is not enough. It is just not possible to convey a message to any audience regardless of their cognitive environment. There is a problem of 'communicability' which is due to the inferential nature of communication and its strong dependence on context.

For Gutt, the message is "the set of assumptions" the original communicator intended to convey. To interpret the intention of the speaker, there should be not only correct decoding of the linguistic contents but also of contextual information as we have seen, and 
in poetry there is the vital component of rhythm, verse, line length, predominance of sounds - all sorts of phonetics-dependent features.

Levy (1969) illustrated the problems that appear when a translator faces the dilemma of close reading and equally close translation, "close" here meaning a practically word-forword rendering of the original. There are instances of poetic prose and descriptive poetry where the translator deviates very little from the original syntax and chooses semantic equivalents without going much beyond what can be found in any acceptable dictionary.

An example of the contrary - where rhyme determines the translator's choice - is furnished by the German writer Christian Morgenstern who has provided translation critics with the canonical example of difficulties in phonetic translation.

\section{Ein Wiesel \\ Sass auf einem Kiesel inmitten Bachgeriesel}

Translation here could be Max Knight's published version "A weasel/perched on an easel/within a patch of teasel." Knight focused on the animal, but the sound of the brook disappears as the rhyme has to be adapted.

But we could forget about which animal was denotated in the original and propose 'A ferret/nibbling a carrot/in a garret' or 'A mink/sipping a drink/in a kitchen sink', etc etc. Or in Spanish 'Una foca/se hace la loca/sentada en una roca' or 'Una marta/come a la carta/en Djakarta' or whichever rhyming animal which is busy doing something in some place.

The context that limits the extension of the readers' search for relevance is very often absent in poetry and the effect depends on a wide range of inference-related features.

The translating of style is central to literary translation: faithfulness is a matter not only of content but also of style. When trying to preserve what someone meant, we do direct translation and when trying to communicate the way it was expressed we do indirect translation. The difference is similar to that between direct and indirect quotation. Direct quotation is chosen for its superficial linguistic properties. A direct quotation reproduces the original stimulus with its various linguistic properties.

The point of preserving stylistic properties lies not in their intrinsic value, but rather in the fact that they provide clues that guide the audience to the interpretation intended by the communicator (Sperber and Wilson 1991:127).

Communicative clues in poetry often arise from phonetic properties, as we have seen. The stress on certain expressions very often carry communicative information and when translating it is not a question of repeating the exact words - or repeating similar words even if their semantic meaning is different. An expression with similar information associated with it has to be found. How far can a translator then go in deviation? Here the text has to be scrutinized: there can be the strengthening of an assumption that act as confirmation for a specific interpretation. Deductive rules apply, and such rules are dependent on the nature 
of conceivable deductive systems, whether psychologically realised or not. That is: from a specific utterance certain information can be inferred. Human deductive abilities allow us to process an enormous amount of different assumptions. But the search for relevance also furnishes limitations: the line of inference can be taken to a certain point but no further, because there are text-internal clues that can not be set aside.

Material for such relevant-bound search for the limits of inference is easy to find both in prose and poetry. The analysis in part 6 . of a poem by Emily Dickinson has been performed with two goals in mind: to try to understand a linguistically puzzling poem and to show what the result of a semantically very close translation has been in this case.

\section{There's a certain Slant of light.}

Among Emily Dickinson's poems there are many that contain descriptions of nature. That does not mean that her descriptions are easy to transfer into another language: her strange punctuation, the bold images and "the wonderfully naked voltage of the poems" (Hughes, 1977) are ingredients that require a translator with a trained and sensitive ear. The translations in M. Manent's selection (Dickinson, 1979) do reveal very little sensitivity, and serve our illustrative purpose perfectly:

There's a certain Slant of light

Winter Afternoons

That oppresses, like the Heft

Of Cathedral Tunes -

Heavenly Hurt, it gives us -

We can find no Scar,

But internal difference

Where the Meanings, are -
Hay una luz sesgada

en las tardes de invierno

que con su peso oprime

como la voz del órgano en un templo.

Una celeste herida

nos hace, mas sin huella:

el alma en el sentido de las cosas

nota la diferencia.

The literal translation was, we have to assume, done with a view to assuring preservation of meaning. The translator has chosen to paraphrase where Dickinson compresses. The translation is not supposed to work on its own as the volume presents source and target texts side by side. Rhyme and rhythm as presented in the original have disappeared totally. The poem is, in spite of the explicating paraphrases, still very difficult to understand. In the first stanza, the paraphrase of "Cathedral Tunes" (5 syllables) extends the line to no less than 12 syllables. The same occurs in the 2 nd stanza. What is more, it can be argued that the last two lines as quoted here have been mis-translated.

Poetic effects arise essentially when the audience is induced and given freedom to open up and consider a wide range of implicatures. Rhyme and rhythm often cross-cut syntactic structure and increase the range of possible interpretations. To mention only one instance in Dickinson's poem, the existence of the rhyming pair scar and are makes stress fall heavily on the last word of the line, which is, furthermore, followed by the typical 
Dickinsonian dash. The 'pair' huella and diferencia allow no endweight. The idea conveyed by the stanza that no external trace of bodily hurt is caused by the shaft of light, but that internal wounds stand open and gaping is not expressed in the translation. The original does not explicitly mention the soul ("el alma") that notices the difference (from what?), but different meanings that cannot be reconciled. To allow relevance-induced interpreting, this idea is vital for comprehension.

The original offers lines of interpretation that are open to readers according to their experience and mood. The relevance of the different lines determine how far they are followed. In the case of the interpretation of the clash between meanings in Dickinson, there is strengthening of the interpretation of the malady of the soul in the third stanza: inferring from the idea of clashing meanings, the reader with a psychoanalytic bent can go further and diagnose schizophrenia.

None may teach it - Any -

'Tis the Seal Despair -

An imperial affliction

Sent us of the Air -
Decir su traza nunca lograrías

porque es el sello, la desesperanza

una aflicción de reyes

que nos envía el aire.

The first two lines are cryptic. In spite of the longwinded explanation they do not make sense in the translation either. Despair can be interpreted as "desesperanza" and "desesperación." If we follow the implications of lack of hope, the affliction is a mortal one. If we strengthen utter despair, the imperial affliction takes on the hint of madness. To decide which line to take, we now go on to the last stanza:

When it comes, the Landscape listens

Shadows - hold their breath

when it goes, 'tis like the Distance

On the look of Death -
Cuando viene, el paisaje presta oído; sin respirar, la sombra ya lo advierte; cuando se aleja, es como la distancia que tiene la mirada de la muerte.

Death. This limits our phychoanalytic line of inference: this is not about madness. It is about the presence of, perhaps longing for, death. The translator has finally found a way of rhyming. But the idea of death holding back, waiting, does not come through.

Back now to square one. Semantic functions may be of higher order than the preserving of rhyme. What features should be preserved? Certainly there is no such thing as one worldview and one interpretation of a poem. But we cannot choose just any interpretation. Connotation - the notion that just about anything the reader might think of or fuzzily imagine is valid in the interpreting of a poem - might be acceptable enough when analysing a poem in its original version. When criticising a translation, a system has to be used that allows us to determine whether inference-triggers have been preserved, and the poetic effects can be exploited to the full. 


\section{Works cited}

Carston, R. "Implicature, Explicature and Truth-Theoretic Semantics". In Davis (Ed.) Pragmatics, A Reader. New York: Oxford UP. 1991, 33-51

Dickinson, Emily. Poemas. Selección y versión de M. Manent. Madrid: Visor, 1979

Gutt, E-A. Translation and Relevance. Cognition and Context. Oxford: Basil Blackwell, 1991.

House, J. A Model for Translation Quality Assessment. Tübingen: Günther Narr, 1981.

Hughes, T. A Selection of Emily Dickinson's Verse. London: Faber and Faber. 1968.

Leclercq, Guy. "Une fête galante revisitée. Analyse et traduction d'une poème de Verlaine." In Palimpsestes n², (199?):29-82. Paris: Publications de la Sorbonne Nouvelle.

Levy, J. Die literarische Übersetzung: Theorie einer Kunstgattung. Frankfurt: Athenäum. 1969

Miller, Elisabeth G. "The Translator's Sensitivity to the Poet's Voice." Translation Review 51 \& 52 (1996): 10-14. The University of Texas at Dallas.

Nida \& Taber. The Theory and Practice of Translation. Leiden:Brill, 1982.

Snell Hornby, M. "On Models and Structures and Target Text Cultures. Methods of Assessing Literary Translations." In Marco Borillo (Ed.) La traducció literaria. Castellón: Publicacions de la Universitat Jaume I. 1995

Short, M. "Discourse Analysis and the Analysis of Drama." In Carter and Simpson (Eds) Language, Literaiure and Discourse. London: Unwin Hyman. 1989, 139-170

Sperber \& Wilson. Relevance. Communication and Cognition. Oxford: Blackwell. 1986.

"Inference and Implicature." In S. Davis (Ed.) Pragmatics. A Reader. New York: Oxford UP. 1991, 377-391.

Varela, E. 1993. "Relevance and Irony: A pragmatic reading of a passage from W. Kennedy." In BabelAfial N²/Invierno de 1993. Orense: Facultad de Humanidades. 69-88. 